\title{
Review Article \\ The Predictive Role of Inflammatory Biomarkers in Atrial Fibrillation as Seen through Neutrophil-Lymphocyte Ratio Mirror
}

\author{
Feliciano Chanana Paquissi \\ Department of Medicine, Clínica Girassol, Luanda, Angola \\ Correspondence should be addressed to Feliciano Chanana Paquissi; fepaquissi@gmail.com
}

Received 18 March 2016; Revised 20 May 2016; Accepted 23 May 2016

Academic Editor: Mark Molloy

Copyright (C) 2016 Feliciano Chanana Paquissi. This is an open access article distributed under the Creative Commons Attribution License, which permits unrestricted use, distribution, and reproduction in any medium, provided the original work is properly cited.

Atrial fibrillation (AF) is the most common arrhythmia and is responsible for significant disease burden worldwide. Current evidence has suggested that systemic inflammatory response plays a crucial role in the initiation, maintenance, and progression of AF. So, recent efforts have been directed in search of measurable inflammatory biomarkers as additional tools in severity and prognosis assessment of AF. A simple, and easily obtainable, inflammatory marker is the neutrophil-lymphocyte ratio (NLR), which has shown good performance in preliminary studies as a potential prognostic biomarker in patients with AF. In this work, we performed a thorough review of clinical studies that evaluated the role of C-reactive protein (CRP), interleukin-6 (IL-6), and NLR as predictors of outcomes in AF. We gave a particular emphasis on the NLR because it is a simpler, widely available, and inexpensive biomarker.

\section{Introduction}

Atrial fibrillation (AF) is the most common cardiac arrhythmia, which in 2010 was estimated to affect about 33.5 million individuals in the world [1], with a prevalence around 2.3$3.4 \%$ among adults [2], and may reach $9 \%$ in those aged over 80 years [3]. Studies point to an increase in both incidence and prevalence $[1,4,5]$, as well as the attributable mortality $[1,5]$, so that between 1990 and $2013 \mathrm{AF}$ was the factor with the greatest relative increase in the burden of cardiovascular diseases (CVDs) [5]. Future projections predict a 2-fold increase in the number of cases of $\mathrm{AF}$ in 2050 [3]. The $\mathrm{AF}$ is associated with significant morbidity and mortality, increasing the risk of stroke and death from all causes $[6,7]$.

Recent investigations have registered significant advances in the understanding of the pathogenic mechanisms underlying $\mathrm{AF}[8,9]$. One of the most explored mechanisms and that has gained more and more space in recent years is the inflammatory response $[10,11]$. The literature has emphasized the role of inflammation in the initiation, maintenance, and progression of $\mathrm{AF}[8,12,13]$. Several inflammatory biomarkers, as C-reactive protein (CRP) and interleukins, have been associated with the occurrence of $\mathrm{AF}$ and its prognosis, including vascular events [10, 14-16]. In fact, the incidence of $\mathrm{AF}$ is increased in other situations that share significant systemic inflammatory response such as nonalcoholic fatty liver disease [17] and metabolic syndrome $[18,19]$, suggesting a role of inflammation as a mediator between atrial fibrillation and these situations.

Among the inflammatory biomarkers, the neutrophillymphocyte ratio (NLR), defined as the ratio of absolute counts of neutrophils and lymphocytes, has emerged recently as effective outcomes predictor in atrial fibrillation [20,21], a role also demonstrated for ischemic heart disease and stroke [22-24]. NLR is a simple, inexpensive, and widely available biomarker and has been shown to be a good predictor of atrial arrhythmias that reflects the role of unbalanced white cells (with the predominance of activated neutrophils) in arrhythmogenesis $[8,9,25]$. 
Multiple inflammatory markers have been studied as predictors of outcomes in $\mathrm{AF}$, from those with potential direct involvement in the pathogenesis, such as IL- 6 and NLR $[11,26]$, and others only as a reflection of underlying immune responses, but apparently without direct participation as CRP [27]. There are those that are being more used in research contexts than in clinical practice. In this paper, we performed a thorough review of clinical studies focusing on CRP, IL-6, and NLR, as they are more reliable in clinical practice, with particular emphasis on the NLR because it is simpler, more widely available, and inexpensive.

\section{Overview of Inflammatory Biomarkers in Atrial Fibrillation}

Several studies have demonstrated the association between inflammatory markers and the incidence, severity, response to treatment, and prognosis in AF [14-16, 28]. An analysis of a large study with 17,120 participants, without prior history of arrhythmia, high-sensitivity C-reactive protein (hsCRP), was associated with a $36 \%$ increase in the risk of developing AF (hazard ratio [HR]: 1.37, p-trend < 0.01) for each increasing tertile above baseline, with persistently high risk, comparing the highest to the lowest hs-CRP tertile, even after adjustment for potential confounders (hazard ratio [HR] 1.96; $p<0.01$ ) [29]. In other studies in patients with AF, CRP was a significant predictor of stroke [14, 30] and peripheral embolism [31]. In treated patients who underwent electrical cardioversion, a high hs-CRP was an independent predictor of AF recurrence even after adjusting for confounders variables $[32,33]$. In another study following patients after catheter ablation, a high hs-CRP was an independent predictor of recurrence $(p=0.021)$ during a median follow-up of 15 months [15]. The contribution of inflammation in atrial activity seems to begin early, as demonstrated in a study where a high CRP was an independent risk factor for spontaneous contrast in transesophageal echocardiography [34]. This reflects that electromechanical impairment begins before any electrocardiographic visible dysrhythmia.

Other inflammatories biomarkers associated with AF and its progression are interleukin-6 (IL-6) [35] and interleukin18 [36]. In one of these studies, with 3,762 adults with chronic kidney disease, a high plasma IL-6 level was associated with $\mathrm{AF}$ at baseline (Odds Ratio [OR], 1.61; $p=0.001$ ) and predicted new-onset AF (OR, 1.25; $p=0.03$ ) during a mean follow-up of 3.7 years [35]. In a study with patient in oral anticoagulation for AF, a high-sensitivity interleukin-6 (hsIL6) was a predictor of long-term cardiovascular events (HR 1.97, $p=0.002$ ) and all-cause mortality (HR 2.48, $p<0.001)$ [37]; and adding hsIL6 to the clinical risk scores (CHADS2 and CHA2DS2-VASc) improved the discrimination index value for prediction of long-term cardiovascular events and death [37]. In another study with rhythm control strategy, IL-6 and CRP were significantly higher in those with AF recurrence than in those maintaining sinus rhythm (mean IL-6: 1.84 versus 1.19, $p<0.005$; CRP: 1.24 versus 0.59 , $p<0.005$ ) [38]. Table 1 summarizes the clinical studies that have assessed the role of general inflammatory biomarkers in AF.

\section{The Particular Role of Neutrophil- Lymphocyte Ratio as a Predictive Biomarker in Atrial Fibrillation}

3.1. Incidence and Prevalence. A high NLR is associated with increased incidence of $\mathrm{AF}$, as was evident in a prospective cohort, with 275 patients who underwent nonemergency coronary artery bypass grafting, where the group with postoperative AF had higher preoperative NLR (median 3.0 versus $2.4, p=0.001$ ) [21]. These findings were also evident in a study with patients undergoing coronary angiography, with stent placement, for acute ST-segment elevation myocardial infarction, where those who developed AF had higher postcatheterization NLRs at 48 hours (median 5.23 versus 3.00, $p=0.05$ ) and 96 hours (median 4.67 versus $3.56, p=0.03$ ) [59], suggesting an inflammatory contribution to new-onset postprocedural AF. In another study with diabetic patients, NLR was significantly higher in those with AF than in the AFfree group (mean $2.87 \pm 1.3$ versus $2.2 \pm 1.56, p=0.019$ ) and was an independent risk factor for AF (OR 3.486, $p=0.004)$ using 2.38 as cut-off [60].

3.2. Severity and Incidence of Stroke. A high NLR not only predicts higher incidence of AF but also is a predictor of disease severity and risk of stroke $[61,62]$. In a study with 309 patients with nonvalvular AF, a high NLR (>2.59) was an independent risk factor for the presence of left atrial thrombus on transesophageal echocardiography (TEE) (OR 1.59; $p<0.02)$ [61]. In another study with TEE, a high NLR $(>2.92)$ was a predictor of reduced $(<10 \mathrm{~cm} / \mathrm{sec})$ left atrial appendage wall velocity (LAAWV) in patients with paroxysmal AF [63]. A large retrospective cohort including 32.912 patients with AF showed that each increase in NLR quartile above the lowest was associated with a significant increase in risk of stroke with HRs of 1.11 (0.91-1.35), 1.25 (1.03-1.51), and 1.56 (1.291.88 ) for the second, third, and highest quartiles, respectively; and adding NLR to CHA2DS2-VASc risk score improved the accuracy for prediction of stroke [62]. Even in those in oral anticoagulation, a high NLR level was a predictor of stroke [20].

3.3. Treatment Response and Mortality. A high NLR is also a predictor of poor response to treatment as shown in a study, where it predicted AF recurrence after successful cardioversion with amiodarone [64]. In another study with 251 patients with symptomatic AF who underwent cryoablation, a high preablation NLR $(>3.15)$ was a predictor of postprocedural disease recurrence (HR 2.15, 95\% CI 1.70 to $2.73, p<0.001$ ) [65]. Regarding mortality, no specific study relating NLR and increased mortality in patients with AF was found. However, a high NLR was an independent predictor of short- and longterm mortality in patients with stroke in general (irrespective of being cardioembolic or atherosclerotic) [24, 66, 67]. Table 2 summarizes the clinical studies that have assessed the role of NLR as a prognostic biomarker in AF. 


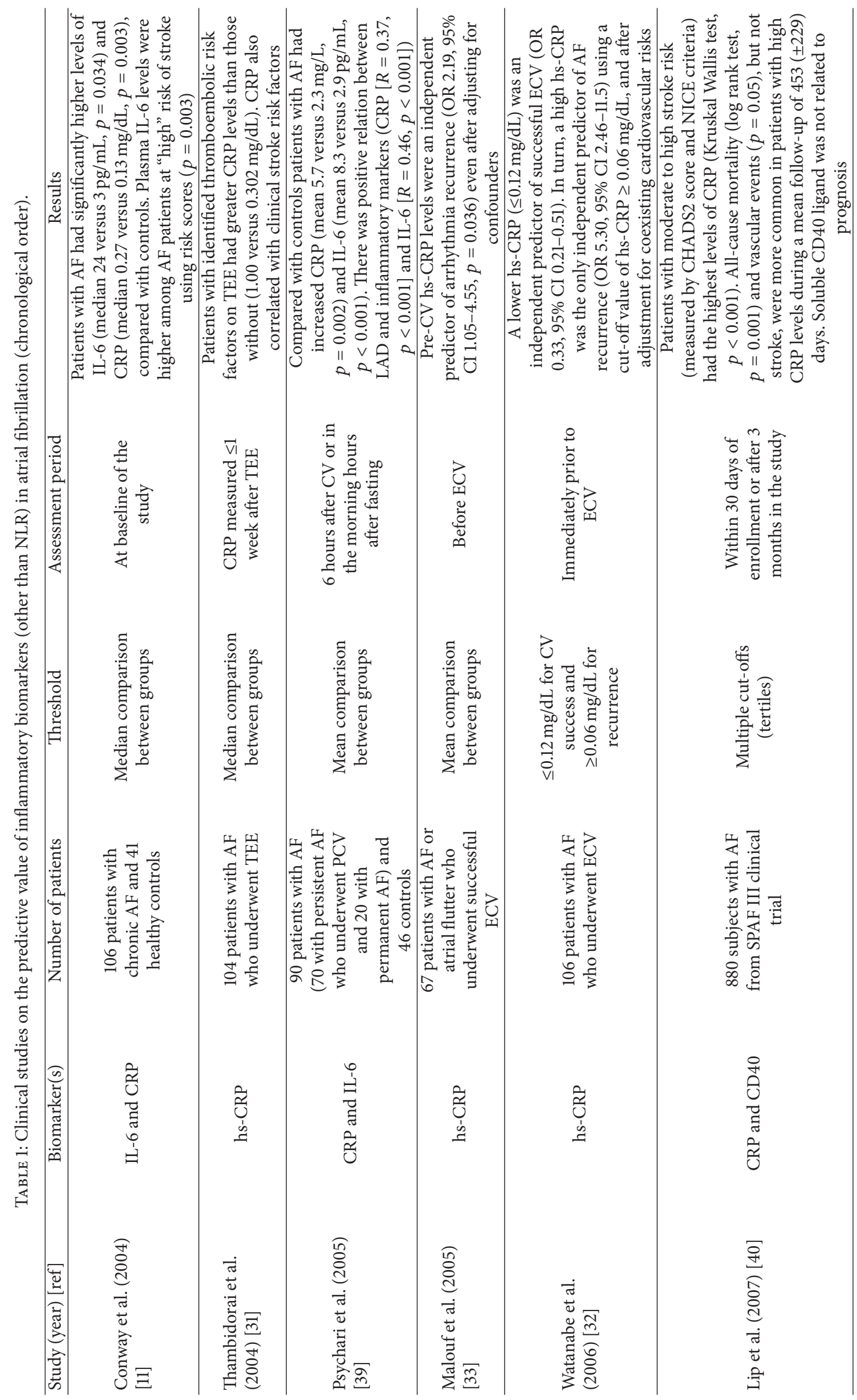




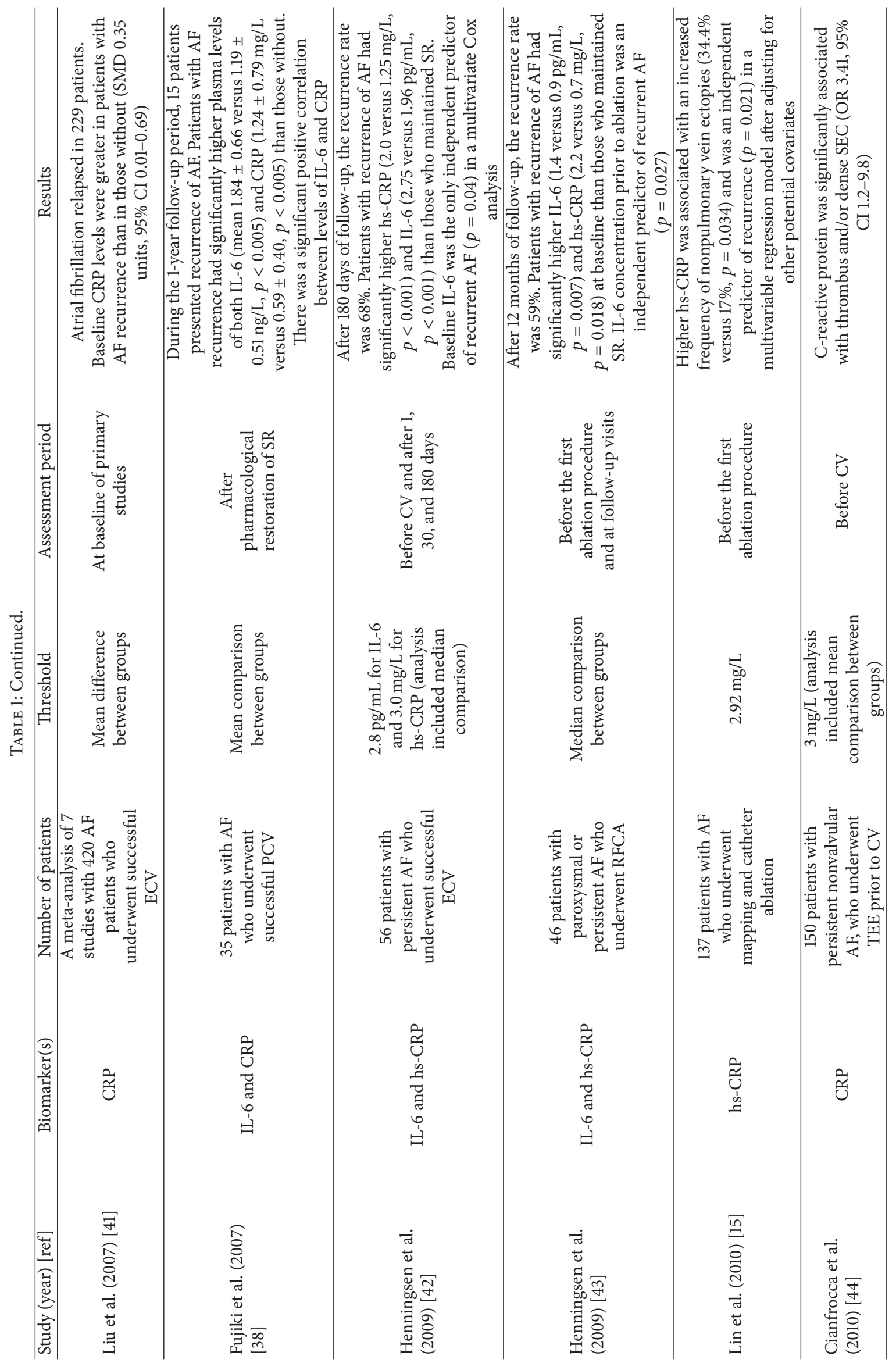




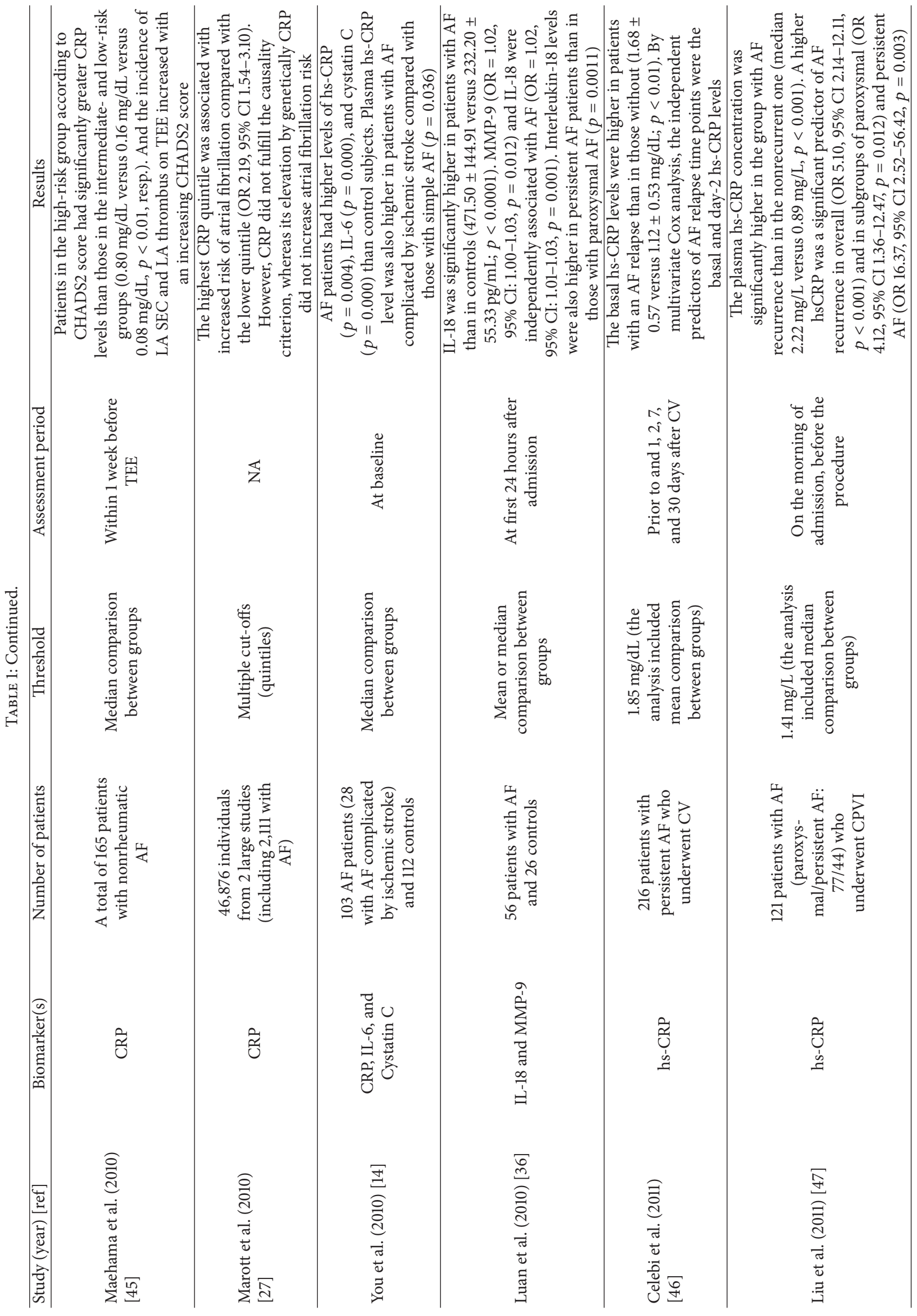




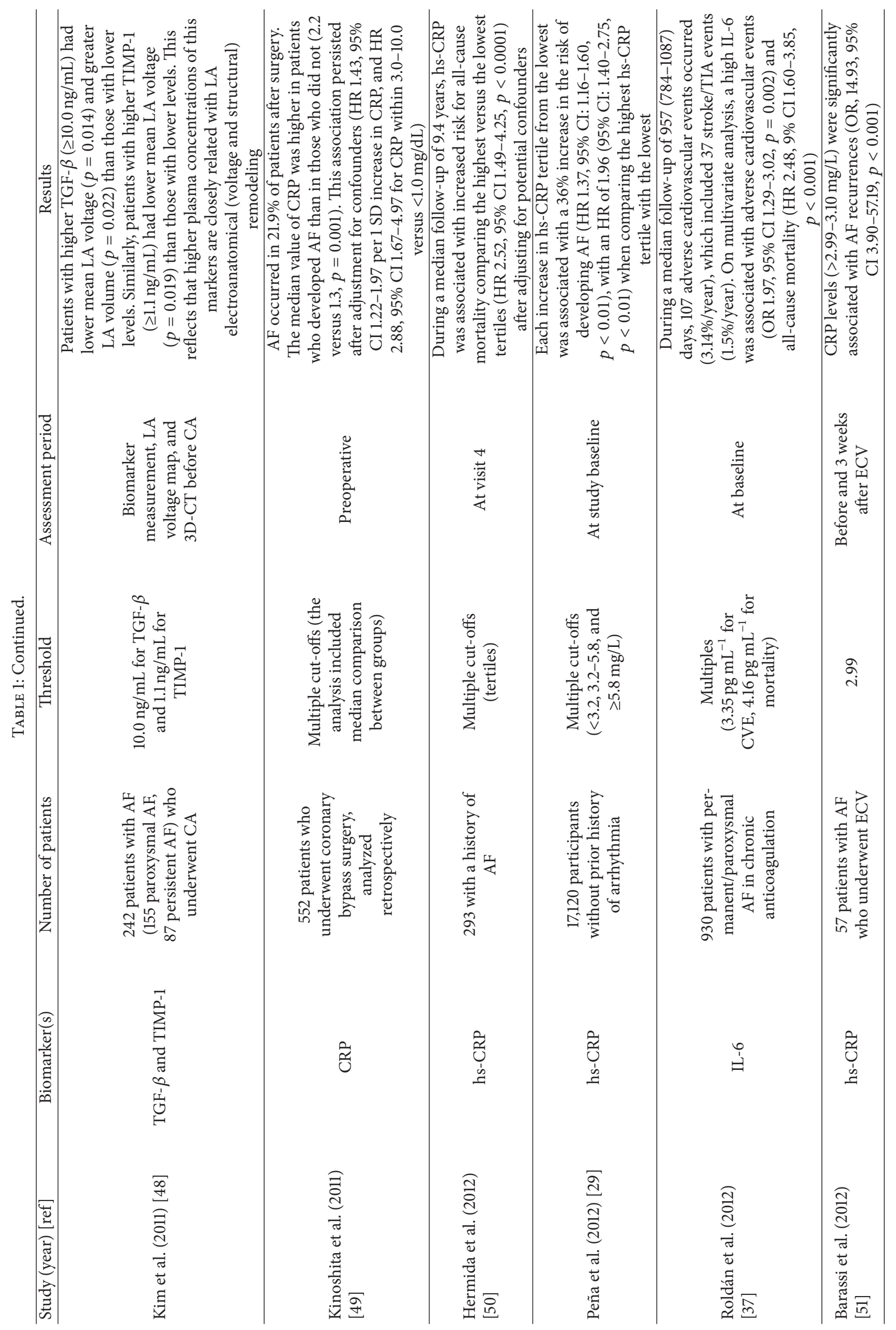




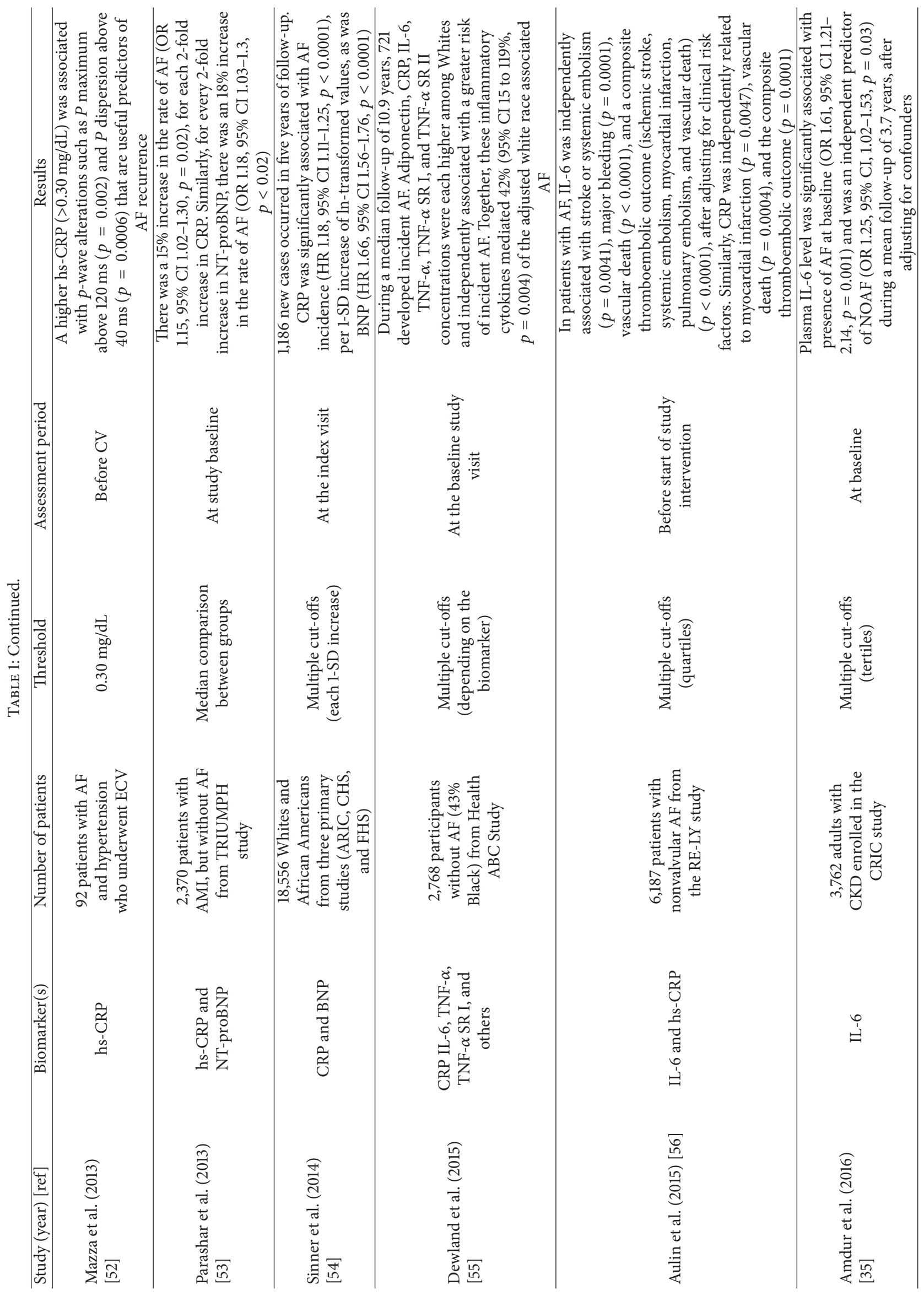




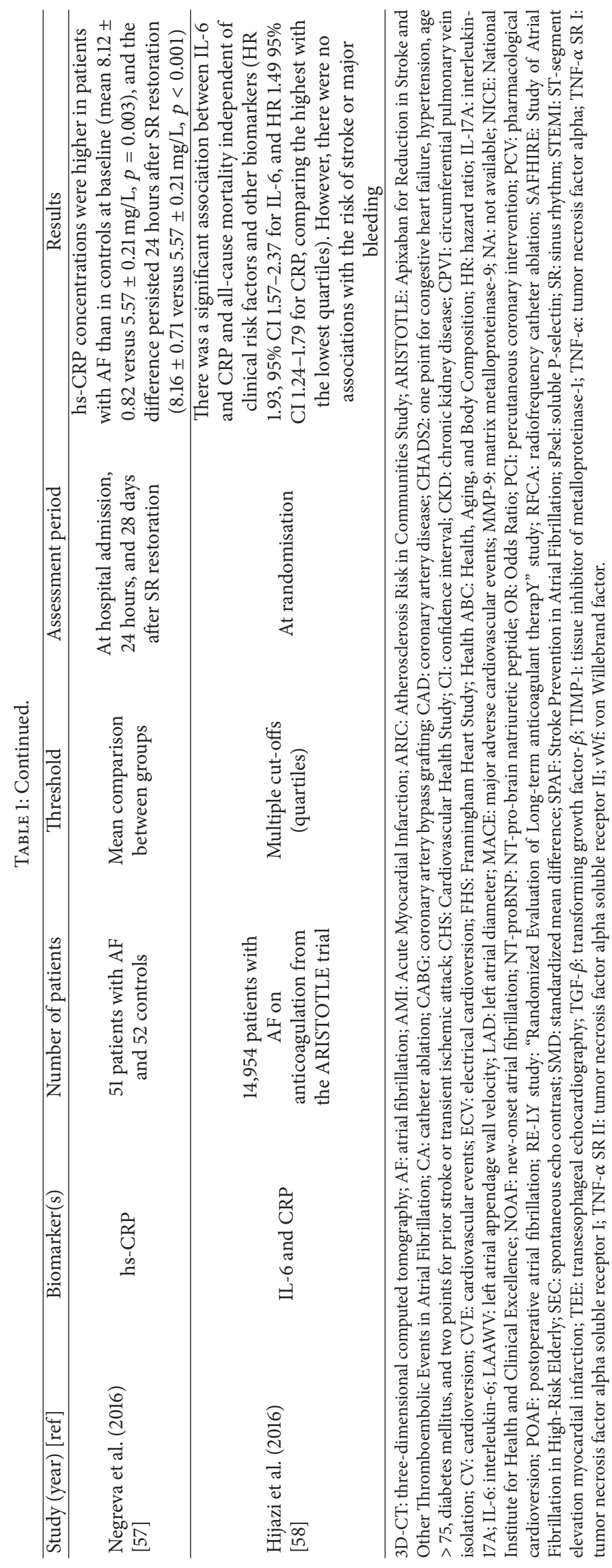


TABLE 2: Clinical studies on the predictive value of the neutrophil-lymphocyte ratio as a biomarker in atrial fibrillation.

\begin{tabular}{|c|c|c|c|c|c|}
\hline Study [ref] & Year & Number of patients & Threshold & $\begin{array}{l}\text { Assessment } \\
\text { period }\end{array}$ & Results \\
\hline $\begin{array}{l}\text { Gibson et al. } \\
{[21]}\end{array}$ & 2010 & $\begin{array}{l}275 \text { patients } \\
\text { without previous } \\
\text { atrial arrhythmia, } \\
\text { undergoing CABG }\end{array}$ & $\begin{array}{l}\text { Median } \\
\text { comparison } \\
\text { between groups }\end{array}$ & $\begin{array}{l}\text { Preoperatively } \\
\text { and on } \\
\text { postoperative } \\
\text { day } 2\end{array}$ & $\begin{array}{l}\text { The incidence of AF was greater in } \\
\text { groups with higher preoperative NLR } \\
\text { (median } 3.0 \text { versus } 2.4, p=0.001 \text { ) and } \\
\text { postoperative NLR (median } 9.2 \text { versus } 7.2 \text {, } \\
\qquad p<0.001 \text { ) }\end{array}$ \\
\hline Ertaş et al. [20] & 2013 & $\begin{array}{l}126 \text { patients with } \\
\text { nonvalvular AF }\end{array}$ & $\begin{array}{l}\text { Mean comparison } \\
\text { among subjects } \\
\text { with or without } \\
\text { stroke }\end{array}$ & At admission & $\begin{array}{l}\text { In patients with nonvalvular AF, mean } \\
\text { NLR was significantly higher among } \\
\text { subjects with stroke compared to } \\
\text { individuals without a stroke (5.6 versus } \\
3.1 \text { ) }\end{array}$ \\
\hline $\begin{array}{l}\text { Canpolat et al. } \\
{[65]}\end{array}$ & 2013 & $\begin{array}{c}251 \text { patients with } \\
\text { symptomatic AF } \\
\text { who underwent } \\
\text { cryoablation }\end{array}$ & 3.15 & Preprocedural & $\begin{array}{l}\text { Patients with a high preablation NLR } \\
(>3.15) \text { had a } 2.5 \text {-fold increased risk of AF } \\
\text { recurrence after successful cryoablation }\end{array}$ \\
\hline Im et al. [68] & 2013 & $\begin{array}{l}499 \text { patients who } \\
\text { underwent RFCA } \\
\text { for paroxysmal or } \\
\text { persistent AF }\end{array}$ & 5.6 & $\begin{array}{l}\text { At baseline and } \\
\text { on day } 1 \text { after } \\
\text { RFCA }\end{array}$ & $\begin{array}{c}\text { In multivariate analysis, a high post-NLR } \\
\text { was an independent predictor for early } \\
\text { recurrence after RFCA (HR } 1.09 ; p \\
0.047) \text {. Patients with higher NLR }(>5.6) \\
\text { had significantly lower AF-free survival } \\
\text { on Kaplan-Meier (K-M) curve }\end{array}$ \\
\hline $\begin{array}{l}\text { Sahin et al. } \\
{[60]}\end{array}$ & 2013 & $\begin{array}{l}144 \text { diabetic } \\
\text { patients }(72 \text { with } \\
\text { and } 72 \text { without } \mathrm{AF})\end{array}$ & $\begin{array}{l}2.38 \text { (analysis } \\
\text { included mean } \\
\text { comparison } \\
\text { between groups) }\end{array}$ & $\begin{array}{l}\text { Retrospectively } \\
\text { recorded from } \\
\text { patient files }\end{array}$ & $\begin{array}{l}\text { The mean NLR was significantly higher in } \\
\text { diabetic patients with AF than in those } \\
\text { without (mean } 2.87 \text { versus } 2.2, p=0.019 \text { ). } \\
\text { Using a cut-off point of } 2.38 \text { NLR was } \\
\text { associated with AF (OR } 3.486, p=0.004 \text { ) }\end{array}$ \\
\hline $\begin{array}{l}\text { Trivedi et al. } \\
{[70]}\end{array}$ & 2013 & $\begin{array}{l}165 \text { patients with } \\
\text { paroxysmal AF, } \\
\text { who underwent } \\
\text { RFCA }\end{array}$ & $\begin{array}{l}3.08 \text { (analysis } \\
\text { included mean } \\
\text { comparison } \\
\text { between groups) }\end{array}$ & $\begin{array}{c}\text { One day prior to } \\
\text { ablation }\end{array}$ & $\begin{array}{c}\text { Baseline NLR was high in patients with } \\
\text { AF recurrence (mean } 3.2 \text { versus } 2.5 \text {, } \\
p<0.001 \text { ). A high baseline NLR }(>3.08) \\
\text { was a significant predictor of postablation } \\
\text { AF recurrence (HR } 1.99,95 \% \text { CI } \\
1.33-2.96, p=0.001)\end{array}$ \\
\hline Guo et al. [69] & 2014 & $\begin{array}{c}379 \text { lone AF } \\
\text { patients who } \\
\text { underwent } \\
\text { catheter ablation }\end{array}$ & $\begin{array}{l}5.15 \text { (analysis } \\
\text { included mean } \\
\text { comparison } \\
\text { between groups) }\end{array}$ & $\begin{array}{l}\text { Before and after } \\
\text { catheter ablation }\end{array}$ & $\begin{array}{l}\text { The patients who developed AF } \\
\text { recurrence had a higher postablation } \\
\text { NLR than patients with no recurrence } \\
\text { (5.74 versus } 4.66, p<0.001 \text { ). A high } \\
\text { postablation NLR }(>5.15 \text { ) was an } \\
\text { independent predictor of AF recurrence } \\
\text { (HR } 1.514,95 \% \text { CI } 1.36-1.68, p<0.001)\end{array}$ \\
\hline Acet et al. [71] & 2014 & $\begin{array}{l}\text { A total of } 197 \\
\text { subjects ( } 71 \text { with } \\
\text { paroxysmal, } 63 \\
\text { with persis- } \\
\text { tent/permanent } \\
\text { AF, and } 63 \text { AF-free } \\
\text { controls) }\end{array}$ & $\begin{array}{l}2.1 \text { (analysis } \\
\text { included mean } \\
\text { comparison } \\
\text { between groups) }\end{array}$ & At baseline & $\begin{array}{l}\text { Higher NLR }(>2.1) \text { had a significant } \\
\text { relationship with nonvalvular AF (OR } \\
\text { 11.31, } p<0.001) \text { compared with control } \\
\text { group; and the mean value was } \\
\text { significantly higher in those with } \\
\text { persistent/permanent compared to those } \\
\text { with paroxysmal AF }(3.4 \pm 0.6 \text {, versus } 2.5 \\
\pm 0.6, p<0.001)\end{array}$ \\
\hline $\begin{array}{l}\text { Nikoo et al. } \\
{[26]}\end{array}$ & 2014 & $\begin{array}{l}112 \text { AF patients and } \\
107 \text { controls }\end{array}$ & $\begin{array}{l}\text { Mean comparison } \\
\text { between groups }\end{array}$ & At baseline & $\begin{array}{l}\text { A significant positive correlation was } \\
\text { observed between NLR and increased } \\
\text { interleukin-17 (IL-17A) in AF ( } p=0.006) \text {. } \\
\text { Elevated IL-17A, on the other hand, was } \\
\text { significantly increased in patients with } \\
\text { AF compared to controls }(1.28 \pm 3.5 \\
\text { versus } 0.19 \pm 0.64 \mathrm{pg} / \mathrm{mL}, p=0.001)\end{array}$ \\
\hline
\end{tabular}


TABLE 2: Continued.

\begin{tabular}{|c|c|c|c|c|c|}
\hline Study [ref] & Year & Number of patients & Threshold & $\begin{array}{c}\text { Assessment } \\
\text { period }\end{array}$ & Results \\
\hline $\begin{array}{l}\text { Karavelioğlu et } \\
\text { al. [64] }\end{array}$ & 2015 & $\begin{array}{l}218 \text { patients } \\
\text { restored to sinus } \\
\text { rhythm with } \\
\text { amiodarone }\end{array}$ & $\begin{array}{l}\text { Mean comparison } \\
\text { between groups }\end{array}$ & At admission & $\begin{array}{l}\text { A high NLR was an independent } \\
\text { predictor of AF recurrence (OR } 1.584 \\
[1.197-2.095], p=0.001) \text { after successful } \\
\text { cardioversion with amiodarone }\end{array}$ \\
\hline $\begin{array}{l}\text { Yalcin et al. } \\
{[61]}\end{array}$ & 2015 & $\begin{array}{l}309 \text { patients with } \\
\text { nonvalvular AF } \\
\text { who underwent } \\
\text { TEE }\end{array}$ & 2.59 & Before TEE & $\begin{array}{l}\text { A high NLR }(>2.59) \text { was an independent } \\
\text { risk factor for the presence of left atrial } \\
\text { thrombus on TEE (OR } 1.59 ; p<0.02) \text { in } \\
\text { patients with nonvalvular AF }\end{array}$ \\
\hline $\begin{array}{l}\text { Saliba et al. } \\
\text { [62] }\end{array}$ & 2015 & $\begin{array}{l}32.912 \text { patients } \\
\text { with AF }\end{array}$ & $\begin{array}{l}\text { Multiple cut-offs in } \\
\text { quartiles }\end{array}$ & $\begin{array}{l}\text { Median NLR } \\
\text { value of the tests } \\
\text { performed in } \\
\text { the year prior to } \\
\text { study entry }\end{array}$ & $\begin{array}{l}\text { Each increase in NLR quartile above the } \\
\text { lowest was associated with a significant } \\
\text { increase in the risk of stroke with HRs } \\
(95 \% \mathrm{CI}) 1.11(0.91-1.35), 1.25 \text { (1.03-1.51), } \\
\text { and } 1.56(1.29-1.88) \text { for the second, third, } \\
\text { and highest quartiles, respectively }\end{array}$ \\
\hline $\begin{array}{l}\text { Chavarria et al. } \\
\text { [59] }\end{array}$ & 2015 & $\begin{array}{l}290 \text { patients who } \\
\text { underwent PCI for } \\
\text { acute STEMI }\end{array}$ & $\begin{array}{l}\text { Median } \\
\text { comparison } \\
\text { between groups }\end{array}$ & $\begin{array}{l}<6 \text { hours } \\
\text { preprocedural, } \\
<12,48 \text {, and } 96 \\
\text { hours } \\
\text { postprocedural }\end{array}$ & $\begin{array}{l}\text { Patients who developed AF }(n=40 \text {, } \\
13.8 \%) \text { had higher postcatheterization } \\
\text { NLR at } 48 \text { hours (median } 5.23 \text { versus } \\
3.00, p=0.05 \text { ) and } 96 \text { hours (median } \\
4.67 \text { versus } 3.56, p=0.03 \text { ) }\end{array}$ \\
\hline $\begin{array}{l}\text { Fukuda et al. } \\
{[63]}\end{array}$ & 2015 & $\begin{array}{l}120 \text { patients with } \\
\text { paroxysmal AF }\end{array}$ & 2.92 & At baseline & $\begin{array}{c}\text { A higher NLR }(>2.92) \text { was a predictor of } \\
\text { reduced LAAWV in patients with } \\
\text { paroxysmal AF }\end{array}$ \\
\hline $\begin{array}{l}\text { Wagdy et al. } \\
{[72]}\end{array}$ & 2016 & $\begin{array}{l}200 \text { patients with } \\
\text { STEMI }\end{array}$ & 4.6 & At admission & $\begin{array}{l}\text { A higher NLR (>4.6) was an independent } \\
\text { predictor of NOAF, no-reflow, and } \\
\text { in-hospital MACE (OR 3.5, } p=0.02) \text { in } \\
\text { patients with STEMI, after adjustment for } \\
\text { confounding factors }\end{array}$ \\
\hline
\end{tabular}

AF: atrial fibrillation; NLR: neutrophil-lymphocyte ratio; OR: Odds Ratio; TEE: transesophageal echocardiography; CABG: coronary artery bypass grafting; RFCA: radiofrequency catheter ablation; NOAF: new-onset atrial fibrillation; LAAWV: left atrial appendage wall velocity; NA: not available; STEMI: STsegment elevation myocardial infarction; CI: confidence interval; IL-17A: interleukin-17A; MACE: major adverse cardiovascular events; PCI: percutaneous coronary intervention.

\section{Underlying Mechanisms, Pathways, and Relationship between Biomarkers in AF}

In relation to the underlying mechanisms, despite the consistency of the studies regarding the epidemiological association between inflammation and AF, there is still a substantial scarcity of data in basic sciences giving the pathophysiologic background to this link. In the case of the CRP, an acute phase protein, it seems to be more a marker of underlying immune responses than an active participant in the pathogenesis of the disease. This is reinforced by the fact that genetic polymorphisms that are associated with the double increase in CRP showed no significant association with the AF [27]. On the other hand, multiple factors interfere with CRP that would be very difficult to control in primary studies, to evaluate possible pathophysiological nexus. For this reason, we focus our description more on those related to NLR, and IL-6, which are more than simple reflectors, seeming to be actively involved in the pathogenesis of AF.

Neutrophil-lymphocyte ratio is a derived marker, expressing an imbalance in leukocytes with the dominance of neutrophils over lymphocytes, which may be only the "tip of the iceberg" of a deeper imbalance in the immunologic response. This seems particularly true from the observation that a high NLR is associated with the excessive activation of interleukin-17 (IL-17) axis in AF [26], which is a cytokine produced mainly by T-helper 17 (Th17) a subset of T-helper cells. In fact, the differentiation of Th17 cells from naïve $\mathrm{T}$ cells is mediated largely by IL-6 [73-75], a cytokine produced mainly by macrophages, which are neutrophils infiltrating tissues. So, IL-6 would induce, at T-helper cells level, the polarization of the differentiation favoring the effectors Th17 cells over the regulatory $\mathrm{T}$ (Treg) cells [76]. Th17 cells produce IL-17 that, among other functions, is responsible for the increase in fibrosis, which is a crucial component in $\mathrm{AF}$ [77-80]. It is interesting that those diseases that have the IL-17 as a cornerstone of its pathophysiology, like psoriasis, or with significant increase of its levels such as nonalcoholic fatty liver disease and metabolic syndrome are associated with increased incidence of AF [17, 19, 81-83], suggesting a role of this cytokine as a mediator between $\mathrm{AF}$ and these clinical conditions.

The IL-17 is also associated with the upregulation of transforming growth factor beta (TGF- $\beta$ ) signaling pathways [84], another potent promoter of atrial fibrosis and consequent AF [85-87]. In addition, IL-17 stimulates the production of more 
proinflammatory cytokines such as tumor necrosis factor(TNF-) $\alpha$ and IL-6 $[88,89]$ and regulates tissue infiltration by neutrophils and myocyte apoptosis, which can start and engage various other pathophysiological pathways including oxidative stress and hypercoagulability [90-92]. IL-17 induces the production of IL-6, a potent inductor of IL-17 synthesis, occurring in this way, a refeeding on the axis $[73,74]$.

The IL-6, as we described, plays a critical role in the regulation of IL-17 axis [73, 75]. IL-6, together with IL23 , induces the differentiation of Th17 cells from naive $\mathrm{T}$ cells, at the same time that inhibits TGF-beta-induced Treg differentiation, favoring, in this way, the T17/Treg imbalance $[73,74,76]$. There is still a significant gap between the epidemiological evidence of inflammation in AF and the current understanding of underlying physiopathological basis. The clear understanding of this association is still an object of future studies from basic science to clinical practice level.

\section{Concerns and Limitations of the Use of Inflammatory Biomarkers in AF}

The main concerns and doubts that arises from the potential use of inflammatory biomarkers in AF is about the additional value of using a panel of two or more biomarkers in predicting AF outcomes than the isolated use, and if there is a superiority of a biomarker in relation to others in AF. No primary study has evaluated the additional value of two or more biomarkers in comparison with the isolated use. Even studies that studied the correlation between biomarkers [11, 14, 38] did not evaluate the additive effect of them to predict outcomes. Despite this gap, it is very likely that in clinical practice a panel of 2 biomarkers or more may be better than the isolated use of one, for predicting AF-related outcomes. So, the evaluation of the additive effect of combined use should be a subject for future studies. On the other hand, the primary studies are very controversial about the superiority of a biomarker in relation to others. So, in light of the current literature, there are no sufficient data to support such point, highlighting only that NLR is more easily accessible and inexpensive than other biomarkers as hs-CRP and IL-6.

\section{Conclusion and Future Directions}

The review of the available evidence shows that inflammatory biomarkers such as IL-6, IL-17, and NLR have a crucial role in the pathogenesis of AF. They represent an additional, noninvasive tool, with good performance, to predict newonset disease, persistence, treatment response, recurrence, the risk of complications, and mortality in AF. The available evidence suggests that NLR, a simpler, widely available, and inexpensive biomarker, is a predictor of incidence, treatment success, recurrence, and thromboembolic complications.

Next studies should be addressed to clarify the underlying mechanisms in AF, to establish the additional value of using a panel of two or more biomarkers in predicting AF outcomes, to evaluate the superiority of a biomarker in relation to others, and to test the value of different biomarkers in different situations in the setting of AF.

\section{Competing Interests}

The author declares no conflict of interests.

\section{References}

[1] S. S. Chugh, R. Havmoeller, K. Narayanan et al., "Worldwide epidemiology of atrial fibrillation: a global burden of disease 2010 study," Circulation, vol. 129, no. 8, pp. 837-847, 2014.

[2] J. Ball, M. J. Carrington, J. J. V. McMurray, and S. Stewart, "Atrial fibrillation: profile and burden of an evolving epidemic in the 21st century," International Journal of Cardiology, vol. 167, no. 5, pp. 1807-1824, 2013.

[3] A. S. Go, E. M. Hylek, K. A. Phillips et al., "Prevalence of diagnosed atrial fibrillation in adults: national implications for rhythm management and stroke prevention: the anticoagulation and risk factors in atrial fibrillation (ATRIA) study," Journal of the American Medical Association, vol. 285, no. 18, pp. 2370$2375,2001$.

[4] R. B. Schnabel, X. Yin, P. Gona et al., "50 Year trends in atrial fibrillation prevalence, incidence, risk factors, and mortality in the Framingham Heart Study: a cohort study," The Lancet, vol. 386, no. 9989, pp. 154-162, 2015.

[5] GBD 2013 Mortality and Causes of Death Collaborators, "Global, regional, and national age-sex specific all-cause and cause-specific mortality for 240 causes of death, 1990-2013: a systematic analysis for the Global Burden of Disease Study 2013," The Lancet, vol. 385, no. 9963, pp. 117-171, 2015.

[6] K.-L. Chien, T.-C. Su, H.-C. Hsu et al., "Atrial fibrillation prevalence, incidence and risk of stroke and all-cause death among Chinese," International Journal of Cardiology, vol. 139, no. 2, pp. 173-180, 2010.

[7] C. Marini, F. De Santis, S. Sacco et al., "Contribution of atrial fibrillation to incidence and outcome of ischemic stroke: results from a population-based study," Stroke, vol. 36, no. 6, pp. 11151119, 2005.

[8] M. D. M. Engelmann and J. H. Svendsen, "Inflammation in the genesis and perpetuation of atrial fibrillation," European Heart Journal, vol. 26, no. 20, pp. 2083-2092, 2005.

[9] Y.-F. Hu, Y.-J. Chen, Y.-J. Lin, and S.-A. Chen, "Inflammation and the pathogenesis of atrial fibrillation," Nature Reviews Cardiology, vol. 12, no. 4, pp. 230-243, 2015.

[10] R. J. Aviles, D. O. Martin, C. Apperson-Hansen et al., "Inflammation as a risk factor for atrial fibrillation," Circulation, vol. 108, no. 24, pp. 3006-3010, 2003.

[11] D. S. G. Conway, P. Buggins, E. Hughes, and G. Y. H. Lip, "Relationship of interleukin-6 and C-reactive protein to the prothrombotic state in chronic atrial fibrillation," Journal of the American College of Cardiology, vol. 43, no. 11, pp. 2075-2082, 2004.

[12] T. T. Issac, H. Dokainish, and N. M. Lakkis, "Role of inflammation in initiation and perpetuation of atrial fibrillation. a systematic review of the published data," Journal of the American College of Cardiology, vol. 50, no. 21, pp. 2021-2028, 2007.

[13] M. Harada, D. R. Van Wagoner, and S. Nattel, "Role of inflammation in atrial fibrillation pathophysiology and management," Circulation Journal, vol. 79, no. 3, pp. 495-502, 2015.

[14] L. You, P. Wang, J. Lv, K. Cianflone, D. Wang, and C. Zhao, "The role of high-sensitivity C-reactive protein, interleukin-6 and cystatin C in ischemic stroke complicating atrial fibrillation," Journal of Huazhong University of Science and Technology, vol. 30, no. 5, pp. 648-651, 2010. 
[15] Y.-J. Lin, H.-M. Tsao, S.-L. Chang et al., "Prognostic implications of the high-sensitive C-reactive protein in the catheter ablation of atrial fibrillation," The American Journal of Cardiology, vol. 105, no. 4, pp. 495-501, 2010.

[16] D. S. G. Conway, P. Buggins, E. Hughes, and G. Y. H. Lip, "Prognostic significance of raised plasma levels of interleukin6 and C-reactive protein in atrial fibrillation," American Heart Journal, vol. 148, no. 3, pp. 462-466, 2004.

[17] G. Targher, F. Valbusa, S. Bonapace et al., "Non-alcoholic fatty liver disease is associated with an increased incidence of atrial fibrillation in patients with type 2 diabetes," PLoS ONE, vol. 8 , no. 2, Article ID e57183, 2013.

[18] H. Watanabe, N. Tanabe, T. Watanabe et al., "Metabolic syndrome and risk of development of atrial fibrillation: the Niigata preventive medicine study," Circulation, vol. 117, no. 10, pp. 12551260, 2008.

[19] A. M. Chamberlain, S. K. Agarwal, M. Ambrose, A. R. Folsom, E. Z. Soliman, and A. Alonso, "Metabolic syndrome and incidence of atrial fibrillation among blacks and whites in the Atherosclerosis Risk in Communities (ARIC) study," American Heart Journal, vol. 159, no. 5, pp. 850-856, 2010.

[20] G. Ertaş, O. Sönmez, M. Turfan et al., "Neutrophil/lymphocyte ratio is associated with thromboembolic stroke in patients with non-valvular atrial fibrillation," Journal of the Neurological Sciences, vol. 324, no. 1-2, pp. 49-52, 2013.

[21] P. H. Gibson, B. H. Cuthbertson, B. L. Croal et al., "Usefulness of neutrophil/lymphocyte ratio as predictor of new-onset atrial fibrillation after coronary artery bypass grafting," The American Journal of Cardiology, vol. 105, no. 2, pp. 186-191, 2010.

[22] B. D. Horne, J. L. Anderson, J. M. John et al., "Which white blood cell subtypes predict increased cardiovascular risk?" Journal of the American College of Cardiology, vol. 45, no. 10, pp. 1638-1643, 2005.

[23] Y. Arbel, A. Finkelstein, A. Halkin et al., "Neutrophil/lymphocyte ratio is related to the severity of coronary artery disease and clinical outcome in patients undergoing angiography," Atherosclerosis, vol. 225, no. 2, pp. 456-460, 2012.

[24] S. Tokgoz, M. Kayrak, Z. Akpinar, A. Seyithanoğlu, F. Güney, and B. Yürüten, "Neutrophil lymphocyte ratio as a predictor of stroke," Journal of Stroke and Cerebrovascular Diseases, vol. 22, no. 7, pp. 1169-1174, 2013.

[25] S. Chatterjee, P. Chandra, G. Guha et al., "Pre-procedural elevated white blood cell count and neutrophil- lymphocyte $(\mathrm{N} / \mathrm{L})$ ratio are predictors of ventricular arrhythmias during percutaneous coronary intervention," Cardiovascular \& Hematological Disorders-Drug Targets, vol. 11, no. 2, pp. 58-60, 2011.

[26] M. H. Nikoo, S. R. Taghavian, H. Golmoghaddam, N. Arandi, A. A. Ardekani, and M. Doroudchi, "Increased IL-17A in atrial fibrillation correlates with neutrophil to lymphocyte ratio," Iranian Journal of Immunology, vol. 11, no. 4, pp. 246-258, 2014.

[27] S. C. W. Marott, B. G. Nordestgaard, J. Zacho et al., "Does elevated C-reactive protein increase atrial fibrillation risk? A mendelian randomization of 47,000 individuals from the general population," Journal of the American College of Cardiology, vol. 56, no. 10, pp. 789-795, 2010.

[28] M. K. Chung, D. O. Martin, D. Sprecher et al., "C-reactive protein elevation in patients with atrial arrhythmias: inflammatory mechanisms and persistence of atrial fibrillation," Circulation, vol. 104, no. 24, pp. 2886-2891, 2001.

[29] J. M. Peña, J. MacFadyen, R. J. Glynn, and P. M. Ridker, "High-sensitivity C-reactive protein, statin therapy, and risks of atrial fibrillation: an exploratory analysis of the JUPITER trial," European Heart Journal, vol. 33, no. 4, pp. 531-537, 2012.

[30] W. T. O’Neal, E. Z. Soliman, G. Howard et al., "Inflammation and hemostasis in atrial fibrillation and coronary heart disease: the REasons for Geographic And Racial Differences in Stroke study," Atherosclerosis, vol. 243, no. 1, pp. 192-197, 2015.

[31] S. K. Thambidorai, K. Parakh, D. O. Martin et al., "Relation of C-reactive protein correlates with risk of thromboembolism in patients with atrial fibrillation," The American Journal of Cardiology, vol. 94, no. 6, pp. 805-807, 2004.

[32] E. Watanabe, T. Arakawa, T. Uchiyama, I. Kodama, and H. Hishida, "High-sensitivity C-reactive protein is predictive of successful cardioversion for atrial fibrillation and maintenance of sinus rhythm after conversion," International Journal of Cardiology, vol. 108, no. 3, pp. 346-353, 2006.

[33] J. F. Malouf, R. Kanagala, F. O. Al Atawi et al., "High sensitivity C-reactive protein: a novel predictor for recurrence of atrial fibrillation after successful cardioversion," Journal of the American College of Cardiology, vol. 46, no. 7, pp. 1284-1287, 2005.

[34] D. S. G. Conway, P. Buggins, E. Hughes, and G. Y. H. Lip, "Relation of interleukin-6, C-reactive protein, and the prothrombotic state to transesophageal echocardiographic findings in atrial fibrillation," The American Journal of Cardiology, vol. 93, no. 11, pp. 1368-1373, 2004.

[35] R. L. Amdur, M. Mukherjee, A. Go et al., "Interleukin-6 is a risk factor for atrial fibrillation in chronic kidney disease: findings from the CRIC study," PLoS ONE, vol. 11, no. 2, Article ID e0148189, 2016.

[36] Y. Luan, Y. Guo, S. Li et al., "Interleukin-18 among atrial fibrillation patients in the absence of structural heart disease," Europace, vol. 12, no. 12, pp. 1713-1718, 2010.

[37] V. Roldán, F. Marín, J. Díaz et al., "High sensitivity cardiac troponin $\mathrm{T}$ and interleukin- 6 predict adverse cardiovascular events and mortality in anticoagulated patients with atrial fibrillation," Journal of Thrombosis and Haemostasis, vol. 10, no. 8, pp. 1500-1507, 2012.

[38] A. Fujiki, T. Sakamoto, K. Nishida, K. Mizumaki, and H. Inoue, "Relation of interleukin-6 and C-reactive protein levels to sinus maintenance after pharmacological cardioversion in persistent atrial fibrillation," Journal of Cardiovascular Pharmacology, vol. 50, no. 3, pp. 264-266, 2007.

[39] S. N. Psychari, T. S. Apostolou, L. Sinos, E. Hamodraka, G. Liakos, and D. T. Kremastinos, "Relation of elevated C-reactive protein and interleukin-6 levels to left atrial size and duration of episodes in patients with atrial fibrillation," The American Journal of Cardiology, vol. 95, no. 6, pp. 764-767, 2005.

[40] G. Y. H. Lip, J. V. Patel, E. Hughes, and R. G. Hart, "Highsensitivity C-reactive protein and soluble CD40 ligand as indices of inflammation and platelet activation in 880 patients with nonvalvular atrial fibrillation: relationship to stroke risk factors, stroke risk stratification schema, and prognosis," Stroke, vol. 38, no. 4, pp. 1229-1237, 2007.

[41] T. Liu, G. Li, L. Li, and P. Korantzopoulos, "Association between C-reactive protein and recurrence of atrial fibrillation after successful electrical cardioversion. a meta-analysis," Journal of the American College of Cardiology, vol. 49, no. 15, pp. 1642$1648,2007$.

[42] K. M. A. Henningsen, S. K. Therkelsen, H. Bruunsgaard, K. S. Krabbe, B. K. Pedersen, and J. H. Svendsen, "Prognostic impact of hs-CRP and IL-6 in patients with persistent atrial fibrillation treated with electrical cardioversion," Scandinavian Journal of 
Clinical and Laboratory Investigation, vol. 69, no. 3, pp. 425-432, 2009.

[43] K. M. A. Henningsen, B. Nilsson, H. Bruunsgaard, X. Chen, B. K. Pedersen, and J. H. Svendsen, "Prognostic impact of hsCRP and IL-6 in patients undergoing radiofrequency catheter ablation for atrial fibrillation," Scandinavian Cardiovascular Journal, vol. 43, no. 5, pp. 285-291, 2009.

[44] C. Cianfrocca, M. L. Loricchio, F. Pelliccia et al., "C-reactive protein and left atrial appendage velocity are independent determinants of the risk of thrombogenesis in patients with atrial fibrillation," International Journal of Cardiology, vol. 142, no. 1, pp. 22-28, 2010.

[45] T. Maehama, H. Okura, K. Imai et al., "Usefulness of CHADS2 score to predict C-reactive protein, left atrial blood stasis, and prognosis in patients with nonrheumatic atrial fibrillation," American Journal of Cardiology, vol. 106, no. 4, pp. 535-538, 2010.

[46] O. O. Celebi, S. Celebi, A. Canbay, G. Ergun, S. Aydogdu, and E. Diker, "The effect of sinus rhythm restoration on high-sensitivity C-reactive protein levels and their association with long-term atrial fibrillation recurrence after electrical cardioversion," Cardiology, vol. 118, no. 3, pp. 168-174, 2011.

[47] J. Liu, P.-H. Fang, S. Dibs, Y. Hou, X.-F. Li, and S. Zhang, "High-sensitivity C-reactive protein as a predictor of atrial fibrillation recurrence after primary circumferential pulmonary vein isolation," Pacing and Clinical Electrophysiology, vol. 34, no. 4, pp. 398-406, 2011.

[48] S. K. Kim, J. H. Park, J. Y. Kim et al., "High plasma concentrations of transforming growth factor- $\beta$ and tissue inhibitor of metalloproteinase-1: potential non-invasive predictors for electroanatomical remodeling of atrium in patients with nonvalvular atrial fibrillation," Circulation Journal, vol. 75, no. 3, pp. 557-564, 2011.

[49] T. Kinoshita, T. Asai, N. Takashima et al., "Preoperative Creactive protein and atrial fibrillation after off-pump coronary bypass surgery," European Journal of Cardio-Thoracic Surgery, vol. 40, no. 6, pp. 1298-1303, 2011.

[50] J. Hermida, F. L. Lopez, R. Montes, K. Matsushita, B. C. Astor, and A. Alonso, "Usefulness of high-sensitivity C-reactive protein to predict mortality in patients with atrial fibrillation (from the Atherosclerosis Risk in Communities [ARIC] study)," The American Journal of Cardiology, vol. 109, no. 1, pp. 95-99, 2012.

[51] A. Barassi, R. Pezzilli, A. M. Morselli-Labate et al., "Serum amyloid a and C-reactive protein independently predict the recurrences of atrial fibrillation after cardioversion in patients with preserved left ventricular function," Canadian Journal of Cardiology, vol. 28, no. 5, pp. 537-541, 2012.

[52] A. Mazza, M. G. Bendini, M. Cristofori et al., "C-reactive protein and $\mathrm{P}$-wave in hypertensive patients after conversion of atrial fibrillation," Journal of Cardiovascular Medicine, vol. 14, no. 7, pp. 520-527, 2013.

[53] S. Parashar, D. Kella, K. J. Reid et al., "New-onset atrial fibrillation after acute myocardial infarction and its relation to admission biomarkers (from the TRIUMPH Registry)," American Journal of Cardiology, vol. 112, no. 9, pp. 1390-1395, 2013.

[54] M. F. Sinner, K. A. Stepas, C. B. Moser et al., "B-type natriuretic peptide and $\mathrm{C}$-reactive protein in the prediction of atrial fibrillation risk: the CHARGE-AF Consortium of communitybased cohort studies," Europace, vol. 16, no. 10, pp. 1426-1433, 2014.
[55] T. A. Dewland, E. Vittinghoff, T. B. Harris et al., "Inflammation as a mediator of the association between race and atrial fibrillation: results from the health $\mathrm{ABC}$ study (Health, Aging, and Body Composition)," JACC: Clinical Electrophysiology, vol. 1, no. 4, pp. 248-255, 2015.

[56] J. Aulin, A. Siegbahn, Z. Hijazi et al., "Interleukin-6 and Creactive protein and risk for death and cardiovascular events in patients with atrial fibrillation," American Heart Journal, vol. 170, no. 6, pp. 1151-1160, 2015.

[57] M. Negreva, S. Georgiev, and K. Prodanova, "Significant Increase in C-Reactive Protein and Serum Amyloid A in the Early Hours of Paroxysmal Atrial Fibrillation," 2016, http://www.cardiologyres.org/index.php/Cardiologyres/article/ view/455/487.

[58] Z. Hijazi, J. Aulin, U. Andersson et al., "Biomarkers of inflammation and risk of cardiovascular events in anticoagulated patients with atrial fibrillation," Heart, vol. 102, no. 7, pp. 508517, 2016.

[59] N. Chavarria, C. Wong, H. Hussain, H. U. L. Joiya, S. Goldbarg, and A. Buda, "Persistent elevation of neutrophil/lymphocyte ratio associated with new onset atrial fibrillation following percutaneous coronary intervention for acute st segment," Journal of Ayub Medical College, Abbottabad, vol. 27, no. 2, pp. 441-447, 2015.

[60] S. Sahin, S. Sarikaya, A. Alcelik et al., "Neutrophil to lymphocyte ratio is a useful predictor of atrial fibrillation in patients with diabetes mellitus," Acta Medica Mediterranea, vol. 29, no. 4, pp. 847-851, 2013.

[61] M. Yalcin, M. Aparci, O. Uz et al., "Neutrophil-lymphocyte ratio may predict left atrial thrombus in patients with nonvalvular atrial fibrillation," Clinical and Applied Thrombosis/Hemostasis, vol. 21, no. 2, pp. 166-171, 2015.

[62] W. Saliba, O. Barnett-Griness, M. Elias, and G. Rennert, "Neutrophil to lymphocyte ratio and risk of a first episode of stroke in patients with atrial fibrillation: a cohort study," Journal of Thrombosis and Haemostasis, vol. 13, no. 11, pp. 1971-1979, 2015.

[63] Y. Fukuda, Y. Nakano, S. Tomomori et al., "Neutrophil to lymphocyte ratio predicts reduced left atrial appendage wall velocity in patients with paroxysmal atrial fibrillation," Journal of Cardiac Failure, vol. 21, no. 10, p. S178, 2015.

[64] Y. Karavelioğlu, H. Karapınar, M. Yüksel et al., "Neutrophil to lymphocyte ratio is predictor of atrial fibrillation recurrence after cardioversion with amiodarone," Clinical and Applied Thrombosis/Hemostasis, vol. 21, no. 1, pp. 5-9, 2015.

[65] U. Canpolat, K. Aytemir, H. Yorgun et al., "Role of preablation neutrophil/lymphocyte ratio on outcomes of cryoballoonbased atrial fibrillation ablation," American Journal of Cardiology, vol. 112, no. 4, pp. 513-519, 2013.

[66] S. D. Brooks, C. Spears, C. Cummings et al., "Admission neutrophil-lymphocyte ratio predicts 90 day outcome after endovascular stroke therapy," Journal of NeuroInterventional Surgery, vol. 6, no. 8, pp. 578-583, 2014.

[67] S. Gökhan, A. Özhasenekler, H. Mansur Durgun, E. Akil, M. Üstündag, and M. Orak, "Neutrophil lymphocyte ratios in stroke subtypes and transient ischemic attack," European Review for Medical and Pharmacological Sciences, vol. 17, no. 5, pp. 653657, 2013.

[68] S. I. Im, S. Y. Shin, J. O. Na et al., "Usefulness of neutrophil/lymphocyte ratio in predicting early recurrence after 
radiofrequency catheter ablation in patients with atrial fibrillation," International Journal of Cardiology, vol. 168, no. 4, pp. 4398-4400, 2013.

[69] X. Y. Guo, S. Zhang, X. L. Yan et al., "Postablation neutrophil/lymphocyte ratio correlates with arrhythmia recurrence after catheter ablation of lone atrial fibrillation," Chinese Medical Journal, vol. 127, no. 6, pp. 1033-1038, 2014.

[70] C. Trivedi, L. Di Biase, S. Mohanty, and P. Mohanty, "Baseline neutrophil/lymphocyte ratio predicts recurrences after radiofrequency catheter ablation: results from prospective study on paroxysmal atrial fibrillation," Circulation, vol. 128, Article ID A18588, 2013.

[71] H. Acet, F. Ertaş, M. A. Akil et al., "New inflammatory predictors for non-valvular atrial fibrillation: echocardiographic epicardial fat thickness and neutrophil to lymphocyte ratio," International Journal of Cardiovascular Imaging, vol. 30, no. 1, pp. 81-89, 2014.

[72] S. Wagdy, M. Sobhy, and M. Louitfi, "Neutrophil/lymphocyte ratio as a predictor of in-hospital major adverse cardiac events, new-onset atrial fibrillation, and no-reflow phenomenon in patients with st elevation myocardial infarction," Clinical Medicine Insights: Cardiology, vol. 10, pp. 19-22, 2016.

[73] L. Zhou, I. I. Ivanov, R. Spolski et al., "IL-6 programs $\mathrm{T}_{\mathrm{H}}$-17 cell differentiation by promoting sequential engagement of the IL21 and IL-23 pathways," Nature Immunology, vol. 8, no. 9, pp. 967-974, 2007.

[74] M. J. McGeachy, K. S. Bak-Jensen, Y. Chen et al., "TGF- $\beta$ and IL6 drive the production of IL-17 and IL-10 by T cells and restrain $\mathrm{T}_{H}$-17 cell-mediated pathology," Nature Immunology, vol. 8, no. 12, pp. 1390-1397, 2007.

[75] P. R. Taylor, S. Roy, S. M. Leal et al., "Activation of neutrophils by autocrine IL-17A-IL-17RC interactions during fungal infection is regulated by IL-6, IL-23, ROR $\gamma \mathrm{t}$ and dectin-2," Nature Immunology, vol. 15, no. 2, pp. 143-151, 2014.

[76] A. Kimura and T. Kishimoto, "IL-6: regulator of Treg/Th17 balance," European Journal of Immunology, vol. 40, no. 7, pp. 1830-1835, 2010.

[77] M. S. Dzeshka, G. Y. H. Lip, V. Snezhitskiy, and E. Shantsila, "Cardiac fibrosis in patients with atrial fibrillation: mechanisms and clinical implications," Journal of the American College of Cardiology, vol. 66, no. 8, pp. 943-959, 2015.

[78] B. Burstein and S. Nattel, "Atrial fibrosis: mechanisms and clinical relevance in atrial fibrillation," Journal of the American College of Cardiology, vol. 51, no. 8, pp. 802-809, 2008.

[79] X.-X. Fu, N. Zhao, Q. Dong et al., "Interleukin-17A contributes to the development of post-operative atrial fibrillation by regulating inflammation and fibrosis in rats with sterile pericarditis," International Journal of Molecular Medicine, vol. 36, no. 1, pp. 83-92, 2015.

[80] W. Feng, W. Li, W. Liu, F. Wang, Y. Li, and W. Yan, "IL-17 induces myocardial fibrosis and enhances RANKL/OPG and MMP/TIMP signaling in isoproterenol-induced heart failure," Experimental and Molecular Pathology, vol. 87, no. 3, pp. 212218, 2009.

[81] O. Ahlehoff, G. H. Gislason, C. H. Jørgensen et al., "Psoriasis and risk of atrial fibrillation and ischaemic stroke: a Danish Nationwide Cohort Study," European Heart Journal, vol. 33, no. 16, pp. 2054-2064, 2012.

[82] O. Ahlehoff, G. Gislason, M. Lamberts et al., "Risk of thromboembolism and fatal stroke in patients with psoriasis and nonvalvular atrial fibrillation: a Danish nationwide cohort study," Journal of Internal Medicine, vol. 277, no. 4, pp. 447-455, 2015.

[83] D. A. Giles, M. E. Moreno-Fernandez, T. E. Stankiewicz et al., "Regulation of inflammation by IL-17A and IL-17F modulates non-alcoholic fatty liver disease pathogenesis," PLoS ONE, vol. 11, no. 2, Article ID e0149783, 2016.

[84] T. Fabre, H. Kared, S. L. Friedman, and N. H. Shoukry, "IL$17 \mathrm{~A}$ enhances the expression of profibrotic genes through upregulation of the TGF- $\beta$ receptor on hepatic stellate cells in a JNK-dependent manner," The Journal of Immunology, vol. 193, no. 8, pp. 3925-3933, 2014.

[85] F. Gramley, J. Lorenzen, E. Koellensperger, K. Kettering, C. Weiss, and T. Munzel, "Atrial fibrosis and atrial fibrillation: the role of the TGF- $\beta 1$ signaling pathway," International Journal of Cardiology, vol. 143, no. 3, pp. 405-413, 2010.

[86] U. Canpolat, A. Oto, T. Hazirolan et al., "A prospective demri study evaluating the role of tgf- $\beta 1$ in left atrial fibrosis and implications for outcomes of cryoballoon-based catheter ablation: new insights into primary fibrotic atriocardiomyopathy," Journal of Cardiovascular Electrophysiology, vol. 26, no. 3, pp. 251-259, 2015.

[87] J. Li, Y. Yang, C. Y. Ng et al., "Association of plasma transforming growth factor- $\beta 1$ levels and the risk of atrial fibrillation: a metaanalysis," PLoS ONE, vol. 11, no. 5, Article ID e0155275, 2016.

[88] J. Chen, M.-Y. Liao, X.-L. Gao et al., "IL-17A induces proinflammatory cytokines production in macrophages via MAPKinases, NF- $\kappa$ B and AP-1," Cellular Physiology and Biochemistry, vol. 32, no. 5, pp. 1265-1274, 2013.

[89] M. Shibata, Y. Shintaku, K. Matsuzaki, and S. Uematsu, “The effect of IL-17 on the production of proinflammatory cytokines and matrix metalloproteinase-1 by human periodontal ligament fibroblasts," Orthodontics and Craniofacial Research, vol. 17, no. 1, pp. 60-68, 2014.

[90] P. Dhillion, K. Wallace, F. Herse et al., "IL-17-mediated oxidative stress is an important stimulator of AT1-AA and hypertension during pregnancy," American Journal of Physiology-Regulatory Integrative and Comparative Physiology, vol. 303, no. 4, pp. R353-R358, 2012.

[91] A. Hot, V. Lenief, and P. Miossec, "Combination of IL-17 and $\mathrm{TNF} \alpha$ induces a pro-inflammatory, pro-coagulant and prothrombotic phenotype in human endothelial cells," Annals of the Rheumatic Diseases, vol. 71, no. 5, pp. 768-776, 2012.

[92] Y.-H. Liao, N. Xia, S.-F. Zhou et al., "Interleukin-17A contributes to myocardial ischemia/reperfusion injury by regulating cardiomyocyte apoptosis and neutrophil infiltration," Journal of the American College of Cardiology, vol. 59, no. 4, pp. 420-429, 2012. 


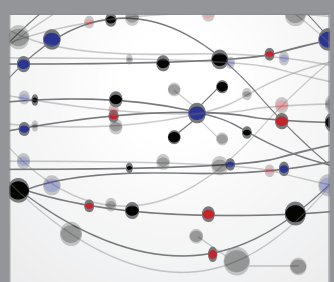

The Scientific World Journal
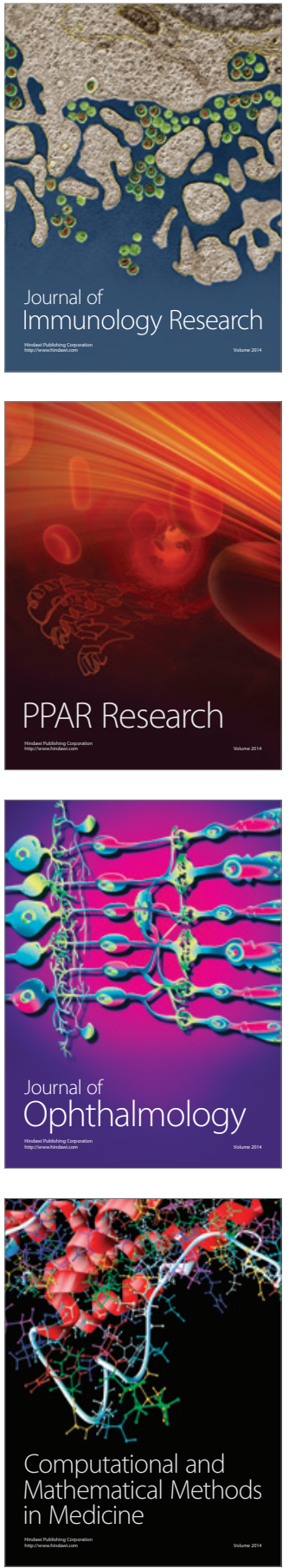

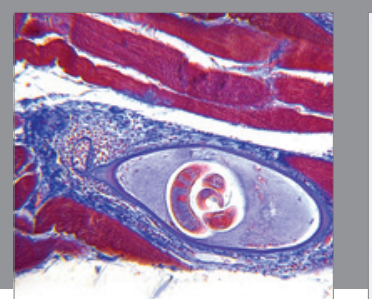

Gastroenterology Research and Practice

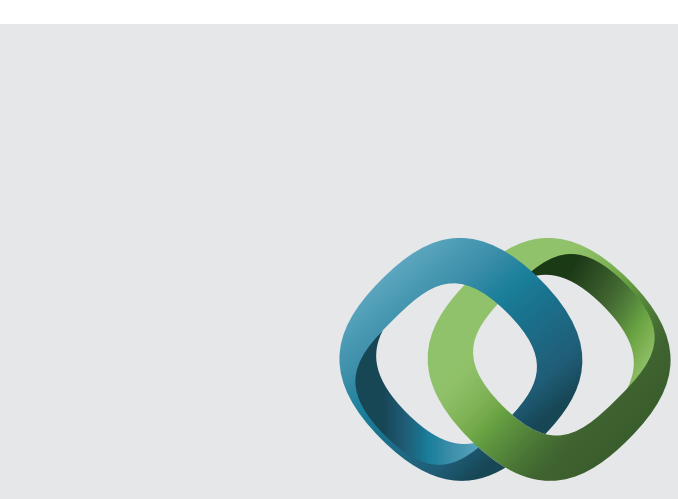

\section{Hindawi}

Submit your manuscripts at

http://www.hindawi.com
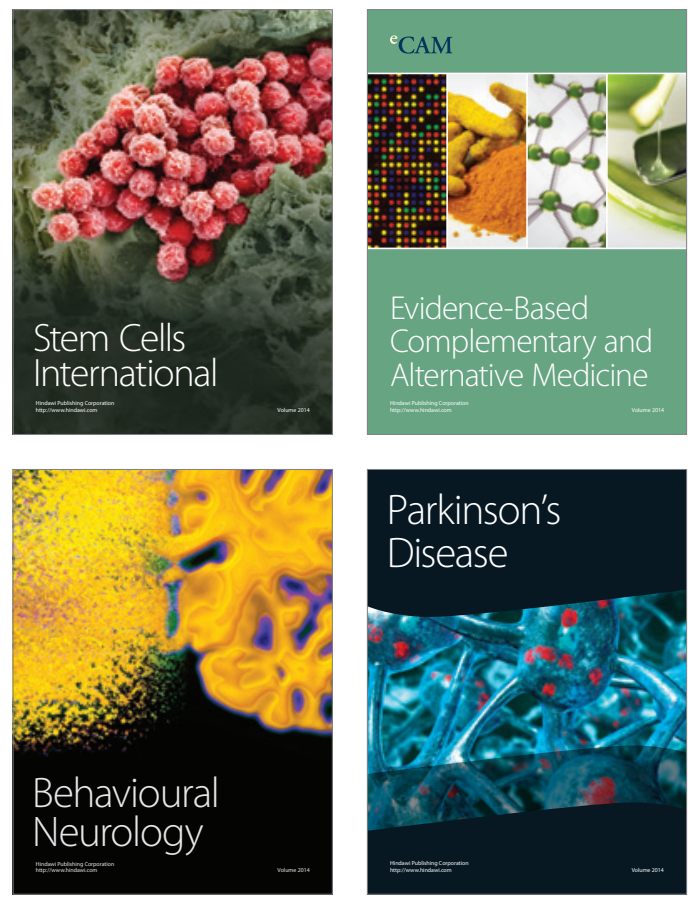
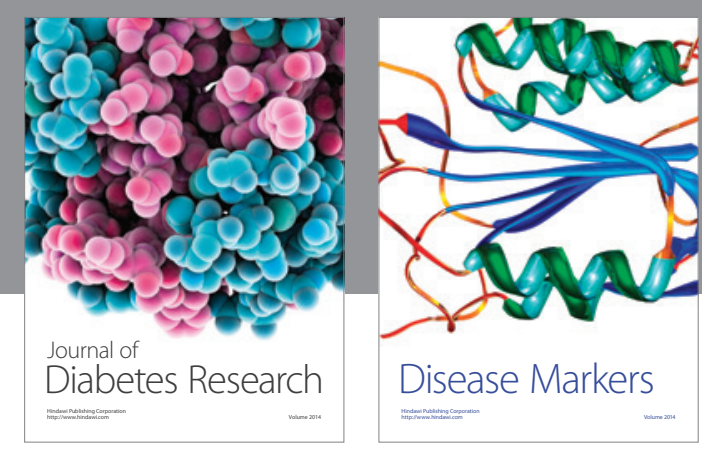

Disease Markers
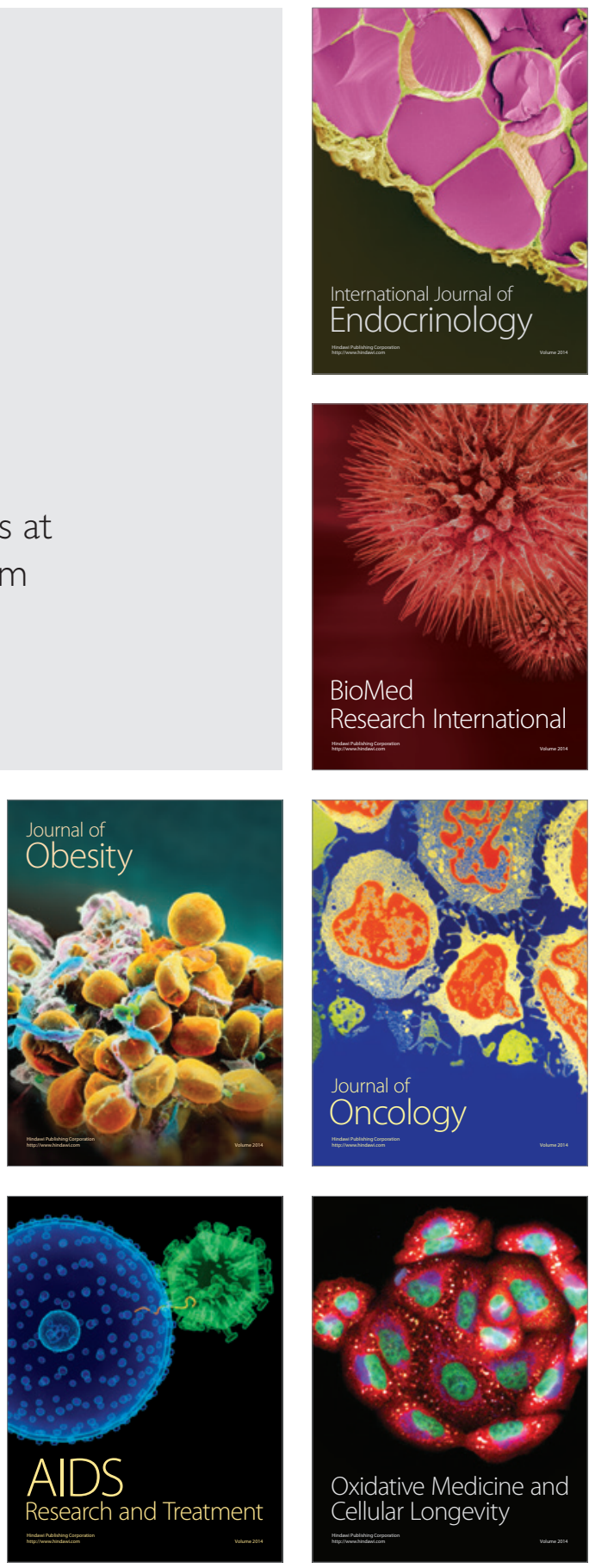